\title{
Chemoprevention of NCI-H322 Lung Cancer Cells Proliferation and Tumor Regression in Murine Ascites Model by Dietary Flavonoid Quercetin
}

\author{
Abid Ali Sheikh 1,*,\# (D), Asif Khurshid Qazi ${ }^{2, \#, ~ A a b i d ~ M a n z o o r ~ S h a h ~}{ }^{1}$, Girish Mahajan ${ }^{2}$, Nazir Ahmad \\ Wani $^{3}$, Abid Hamid ${ }^{2}$, Dilip Manikrao Moondhe ${ }^{2}$ \\ 1 Biotechnology Division, Indian Institute of Integrative Medicine-CSIR Srinagar-190005 (Jammu and Kashmir) India; \\ abidalis2007@gmail.com (A.S); aabidmanzoor87@gmail.com (A.M); \\ 2 Cancer pharmacology Division, Indian Institute of Integrative Medicine-CSIR Jammu-180001(Jammu \&Kashmir) India; \\ qazi_biochem@rediffmail.com (A.K); girishmahajan7800@gmail.com (G.M); abidhamid76@gmail.com (A.H); \\ dmmondhe@iiim.res.in (D.M); \\ 3 Department of Microbiology and Biotechnology, Jnana Bharathi Campus, Bangalore University, Bengaluru-560056, \\ Karnataka, India; nazirwani100@gmail.com (N.A); \\ * Correspondence: abidalis2007@gmail.com (A.S.); \\ \# These authors equally contributed to this work;
}

Scopus Author ID 55250138800

Received: 9.09.2021; Revised: 20.10.2021; Accepted: 24.10.2021; Published: 20.11.2021

\begin{abstract}
Prunus cerasus L (Sour cherries) contain diverse secondary metabolites which exhibit various biological activities, including anticancer, antioxidant, and anti-inflammatory properties. The present study aimed to determine the anticancer efficacy of four compounds, quercetin, daidzin, rutin, and chlorogenic acid, isolated from Prunus cerasus fruit. The antiproliferative activity of four cherry isolates was determined against five different cancer cell lines (NCI-H322, A549, THP-1, MCF-7, and PC-3) by Tetrazolium bromide assay, followed by apoptosis Cell cycle analyses, mitochondrial membrane potential, cell migration test, and in vivo Ehrlich Ascites Carcinoma studies using potent bioactive lead. The cytotoxicity profile of the four molecules demonstrated that quercetin induced significant cell growth inhibition in all cancer cell lines with paramount $79 \%$ cytotoxicity against NCIH322 lung cancer cells $\left(\mathrm{IC}_{50}\right.$ value $\left.24 \mu \mathrm{M}\right)$. Incubation of NCI-H322 cells with quercetin showed a concentration-dependent increase in hypo-diploid sub G0/G1 DNA fraction, exhibited consequential changes in nuclear morphology, and caused mitochondrial transmembrane potential loss of $60.3 \%$ augmented at $30 \mu \mathrm{M}$. Pertaining to in vivo potency, quercetin manifested $89 \%$ tumor inhibition at 50 $\mathrm{mg} / \mathrm{kg}$ body weight in EAC-bearing mice. The current studies raise the potential usefulness of quercetin in chemoprevention against lung cancer cells and support its empirical use as a promising nutraceutical agent.
\end{abstract}

Keywords: quercetin; cancer; apoptosis; NCI-H322, Ehrlich Ascites Carcinoma.

(C) 2021 by the authors. This article is an open-access article distributed under the terms and conditions of the Creative Commons Attribution (CC BY) license (https://creativecommons.org/licenses/by/4.0/).

\section{Introduction}

Cancer is one of the major causes of mortality around the world. In 2020, globally, 19.3 million people will have cancer and causing almost 10.0 million deaths. This burden will double to about 29.4 million new cases by 2040 [1]. The expeditious spread is now arising in low-and middle-income countries, which might contribute around 19.6 million new cancer prognoses every year, i.e., causing approximately $75 \%$ of all cancer-originating deaths. In spite of lead in therapeutic approaches, lung cancer continues to be the leading cause of cancer- 
related deaths worldwide, with incidence and mortality of $11.4 \%$ and $18.0 \%$ (1.8 million deaths), respectively, due to the displeasing prognosis of this metastatic disease [2]. Epidemiological analysis of these cancer cases has manifested that one-third of cancers can be managed by disposing or reducing exposure to risk factors or circumstances, specifically tobacco and tobacco product use, which accounts for $25 \%$ of all cancer deaths globally and about two-thirds of all lung cancer deaths. Lung cancer involves the changes in genetic material caused by mutations due to carcinogenic chemicals, diet, and lifestyle factors, leading to loss of cell homeostasis [3].

Substantial research studies have established that apoptosis provides natural protection against the onset of cancer [4] and restoration of cellular apoptosis process by the intervention of natural products, biological or synthetically developed agents evince a promising chemoprevention approach because of their ability to influence key cellular processes that alter the course of tumor cells [5]. Importantly, both preclinical and clinical published reports have governed that bioactive phytochemicals especially distinctive bioflavonoids, have attracted scientific attention, as they alter the natural history of carcinogenesis [6], especially in the etiology of lung cancer [7]. In the past, berry fruits, including cherries and their bioactive constituents, provided a positive role in the chemoprevention of cancer [8]. Multiple studies have proven that sour cherries possess a broad spectrum of secondary metabolites with versatile biological properties [9]. One of the bioactive flavonoids in P. cerasus fruit and abundant in other ethnomedicinal plant sources is quercetin, having a significant impact on diverse metabolic processes for the management of clinical pathologies to reduce chronic diseases in humans [10].

Cherries, a natural fruit with diverse phytocomposition and various biological properties, has provided an alternative prospect for contribution in cancer chemoprotection. [11]. To further implicate the biological activity data, chemoprevention studies will be conducted on the P. cerasus fruit-derived phytochemicals due to their diverse applications. Against this backdrop, the present study explains the in vitro and in vivo anticancer activity of four compounds isolated from Prunus cerasus fruit.

\section{Materials and Methods}

\subsection{Isolation of pure compounds from sour cherry fruit.}

Methanolic fruit extract of $P$. cerasus was prepared and subjected to column chromatography, which resulted in the isolation of four compounds as quercetin (QCTN), daidzin (DAZ), rutin (RUT), and chlorogenic acid (CHL-A). These four compounds were further purified and characterized, details published in our earlier research study [12].

\subsection{Cell Culture and maintenance.}

The different types of cancer cell lines used in the study included lung cancer cells (NCI-H322, A549), breast cancer cells (MCF-7), prostate (PC-3), and leukemia (THP-1) were procured from the European Collection of Cell Culture (ECACC) institute United kingdom. These cells were grown in RPMI-1640 minimum essential medium (MEM) medium supplemented with $10 \%$ heat-inactivated fetal calf serum and $1 \%$ penicillin. The cells were maintained in a controlled atmosphere of $95 \mathrm{CO}_{2}$ gas and at $37^{\circ} \mathrm{C}$ temperature using a $\mathrm{CO}_{2}$ incubator. Reference cultures for some cell lines were obtained from NCCS Pune, India. 


\subsection{Assay for cell viability.}

The effect of four compounds on cell viability and proliferation using five different human cancer cell lines of varied tissue origin were determined by MTT assay [13]. The cells were grown in a 96-well plate at a density of $6 \times 10^{3}$ cells per well for $24 \mathrm{~h}$. After $24 \mathrm{~h}$, cells were treated with indicated concentrations of pure compounds and incubated for another $48 \mathrm{~h}$. Then $20 \mu \mathrm{l}$ of MTT dye $(2.5 \mathrm{mg} / \mathrm{ml}$ in PBS) was added to each well at 4 hours before the completion of $48 \mathrm{~h}$ incubation period. After that, the supernatant was aspirated, and MTT formazan crystals were dissolved by adding $150 \mu \mathrm{l}$ of DMSO. The observance was measured at $570 \mathrm{~nm}$ by using a microplate reader (Bio-Rad). Mitomycin-C and 5-FU were used as positive controls.

\subsection{Cell cycle analysis by flow cytometry.}

Cell cycle analysis was carried out by flow cytometry using propidium iodide stain. [14]. The lung cancer cells NCIH322 were cultured in 6 well plates at a density of $5 \times 10^{5}$ cells/ml/well overnight and then treated with various concentrations $(5,10,20$, and $30 \mu \mathrm{M})$ of quercetin, and the plate was incubated for $48 \mathrm{~h}$. After $48 \mathrm{~h}$, cells were trypsinized, washed with PBS, then resuspended and fixed with $70 \%$ cold ethanol overnight at $-20^{\circ} \mathrm{C}$. Thereafter, the cells were stained with propidium iodide $(50 \mu \mathrm{g} / \mathrm{ml} \mathrm{IP})$ in the dark for $30 \mathrm{~min}$. The DNA content was measured using BD FACS flow cytometry, and FACS Diva software helped in histogram analyses.

\subsection{Assessment of nuclear morphology.}

The microscopic examination of changes in nuclear morphology after treatment was observed using DAPI stain [15]. The NCI-H322 lung cancer cells were grown in 6 well plates at a density of $5 \times 10^{5}$ cells per well. Then cells were treated with different concentrations of quercetin and incubated for $48 \mathrm{~h}$. Thereafter, the cells were collected and centrifuged at 1600 rpm for $5 \mathrm{~min}$. The pellets were washed with PBS buffer and fixed in methanol for $30 \mathrm{~min}$ at $4^{\circ} \mathrm{C}$. Then cell suspension was stained with $1 \mu \mathrm{g} / \mathrm{ml}$ of 4-6-diamidino-2-phenylindole (DAPI) for $10 \mathrm{~min}$. The cells were centrifuged, and their pellet was suspended in $50 \mu \mathrm{l}$ of mounting fluid (PBS: glycerol, 1:1). Finally, $10 \mu \mathrm{l}$ of this cell suspension was smeared on a glass slide for observation under the inverted fluorescence microscope.

\subsection{Mitochondrial membrane potential.}

The mitochondrial membrane potential was evaluated by using rhodamine 123 dye. [14]. The NCI-H322 $5 \times 10^{5} \mathrm{cells} / \mathrm{ml} /$ well were grown in a 6 well plate overnight. After that, different concentrations of quercetin were added, and the plate was incubated for $48 \mathrm{~h}$. Then rhodamine $(10 \mu \mathrm{g} / \mathrm{ml} \mathrm{Rh-123)}$ was added in the dark, and the plate was further incubated for 30 min, followed by washing these cells with PBS. The pelleted cells obtained after centrifugation were resuspended in $300 \mu 1$ of PBS. The intensity of fluorescence was analyzed by flow cytometry at $485 \mathrm{~nm}$.

\subsection{In vitro cell migration assay.}

This assay was done according to the protocol outlined by a study by Qazi et al., 2015 [14]. The NCI-H322 cancer cells were grown in a 6 well-plate at the density of $5 \times 10^{5}$ cells per 
well overnight. Then cells were wounded in the middle of the well by scratching with a sterile tip. The cells were washed with PBS three times, and fresh media was added. Thereafter different concentrations of test compound quercetin were added, and the plate was incubated for $48 \mathrm{~h}$. The wounds were captured from $0 \mathrm{~h}$ and $24 \mathrm{~h}$.

\subsection{Experimental animals and ethical clearance.}

Swiss albino mice weighing between 18 to $23 \mathrm{~g}$ were housed in well-ventilated standard laboratory conditions of humidity (50-60\%), temperature $25 \pm 2^{\circ} \mathrm{C}$, and $12 \mathrm{~h}$ photoperiod (light/dark). The animals were provided with pelleted mice feed and water ad libitum. All experimental procedures were duly approved by the Institutional Animals Ethics Committee (IAEC), under (CPCSEA registration no. 67/99/CPCSEA) according to the Government of India accepted principles for laboratory animal use and cared under No. 10/1998-99. The studies for in vivo anticancer activity in the mouse model were conducted as per the National Cancer Institute (NCI) USA guidelines [16].

\subsection{In vivo chemoprevention studies of quercetin using EAC model.}

Ehrlich Ascites Carcinoma (EAC) cells were collected from the peritoneal cavity of the non-inbred Swiss mice harboring 8-10 days old ascetic tumor. On the $0^{\text {th }}$ day, 38 non-inbred Swiss mice selected for the experiment received EAC $1 \times 10^{7}$ cells $/ \mathrm{ml}$ through intraperitoneal injection. The next day, the animals were divided into five groups; four treatment groups having seven animals in each group and one untreated control group accommodating ten animals. Groups I, II, and III were treated respectively with 15,30 , and $50 \mathrm{mg} / \mathrm{kg}$ of QCTN intraperitoneally from day 1-9. Group IV was used as positive control and treated with 5fluorouracil (20 mg/kg, i.p.) from day 1-9, whereas similarly, normal saline (0.2 ml, i.p.) was administered in the untreated control group. After 12 days of the experiment, animals were sacrificed, ascitic fluid was collected for estimation of tumor index. Tumor cell growth in control and treated groups were counted, and \% inhibition was calculated as follows: Tumor cell growth in the untreated control group was taken as 100 percent cell growth.

(Av. no. of tumor cells in cont. group - Av. no. of tumor cells in the test group)

$\%$ Tumor inhibition $=$ - -------

Av. no. of tumor cells in cont. group

\subsection{Statistical analysis.}

Results were expressed as mean and standard deviations of triplicates. Statistical comparisons were made by student's t-test, and $\mathrm{p}<0.05$ was considered statistically significant.

\section{Results and Discussion}

\subsection{Inhibition of cell proliferation and determination of $I C_{50}$ values.}

The cytotoxicity efficacy profile of quercetin (QCTN), daidzin (DAZ), rutin (RUT), and chlorogenic acid (CHL-A) at indicated concentrations 10,30 , and $50 \mu \mathrm{M}$ against various cancer cell lines NCI-H322, MCF-7, PC-3, THP-1, and A-549 demonstrated in Table 1. Bioflavonoid quercetin showed significant anticancer activity against all cancer cell lines in a dose-dependent pattern among the four cherry compounds. The maximum cytotoxicity 
quercetin accomplished $79 \%$ against NCI-H322 lung cells, and the minimum effect of $48 \%$ on PC-3 cells was at $50 \mu \mathrm{M}$. However, the other three compounds DAZ, CHL-A, and RTN, showed moderate cytotoxicity against these cell lines. Thus, quercetin posses ses a significant cytotoxicity effect with the least $\mathrm{IC}_{50}$ of $24 \mu \mathrm{M}$ against NCI-H322 lung cancer cells (Figure 1).

Table 1. In vitro cytotoxicity profile of four sour cherry molecules against different human cancer cell lines.

\begin{tabular}{|c|c|c|c|c|c|c|}
\hline \multicolumn{2}{|l|}{ Tissue Type } & Lung & Leukemia & Breast & Prostate & Lung \\
\hline \multicolumn{2}{|l|}{ Cell Line Type } & A-549 & THP-1 & MCF-7 & PC-3 & NCI-H322 \\
\hline Compounds $\mathrm{C}$ & \multicolumn{6}{|c|}{ \% Growth Inhibition } \\
\hline \multirow{3}{*}{ Rutin } & 10 & 05 & 08 & 07 & 03 & 15 \\
\hline & 30 & 14 & 17 & 19 & 12 & 16 \\
\hline & 50 & 36 & 41 & 40 & 28 & 21 \\
\hline \multirow{3}{*}{ Chlorogenic acid } & 10 & 0 & 04 & 12 & 02 & 09 \\
\hline & 30 & 10 & 13 & 26 & 11 & 20 \\
\hline & 50 & 31 & 37 & 41 & 36 & 37 \\
\hline \multirow{3}{*}{ Quercetin } & 10 & 41 & 33 & 43 & 12 & 35 \\
\hline & 30 & 66 & 64 & 57 & 43 & 59 \\
\hline & 50 & 71 & 70 & 68 & 48 & 79 \\
\hline \multirow{3}{*}{ Daidzin } & 10 & 23 & 18 & 07 & 04 & 09 \\
\hline & 30 & 20 & 30 & 35 & 21 & 17 \\
\hline & 50 & 48 & 53 & 50 & 37 & 33 \\
\hline Mitomycin-C & & 71 & - & - & 69 & - \\
\hline 5-FU & & - & 67 & - & - & - \\
\hline
\end{tabular}

Four isolated marker compounds QCTN, DAZ, RUT, and CHL-A, were evaluated for in vitro cytotoxicity against human cancer cell lines employing cell viability assay. The results are expressed as the percent of cell growth inhibition determined relative to untreated control cells.

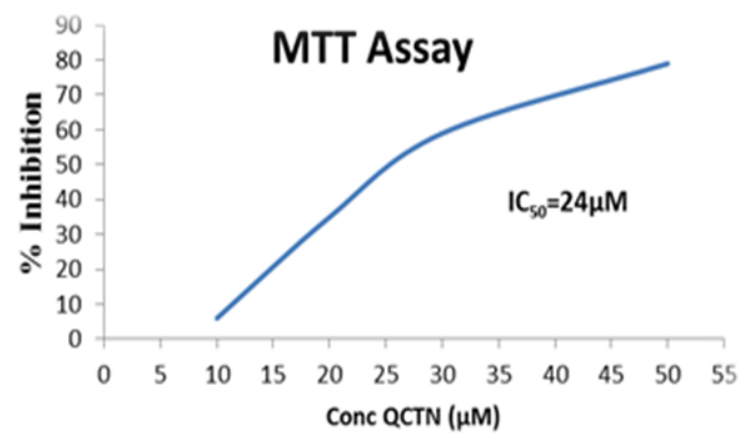

Figure 1. Effect of QCTN on the proliferation of NCIH322 human lung cancer cells. The cells were treated with different concentrations of QCTN for indicated time period \& thereafter, incubated with MTT. Data are mean \pm standard deviation of three similar experiments carried out in triplicate. $\mathrm{IC}_{\mathbf{5 0}}$ : Half maximal inhibitory concentration for QCTN.

\subsection{Cell cycle analysis.}

The cell cycle analysis of NCI-H322 lung cancer cells was evaluated by monitoring an increase in hypo-diploid DNA fractions after $24 \mathrm{~h}$ of quercetin treatment. The sub- $\mathrm{G}_{0}$ population of cells was found to be $31.1,55.2,63.3$, and $74.1 \%$ established respectively at 5 , 10,20 , and $30 \mu \mathrm{M}$ quercetin treatment. At the same time, $12.3 \%$ of cells were observed in the sub- $\mathrm{G}_{0}$ phase in BEZ-235 at $10 \mathrm{nM}$ (Figure 2). Hence results showed that decreased PI fluorescence in untreated control cells reflects the intact membrane while as incubation with quercetin produced a significant change in this parameter. 

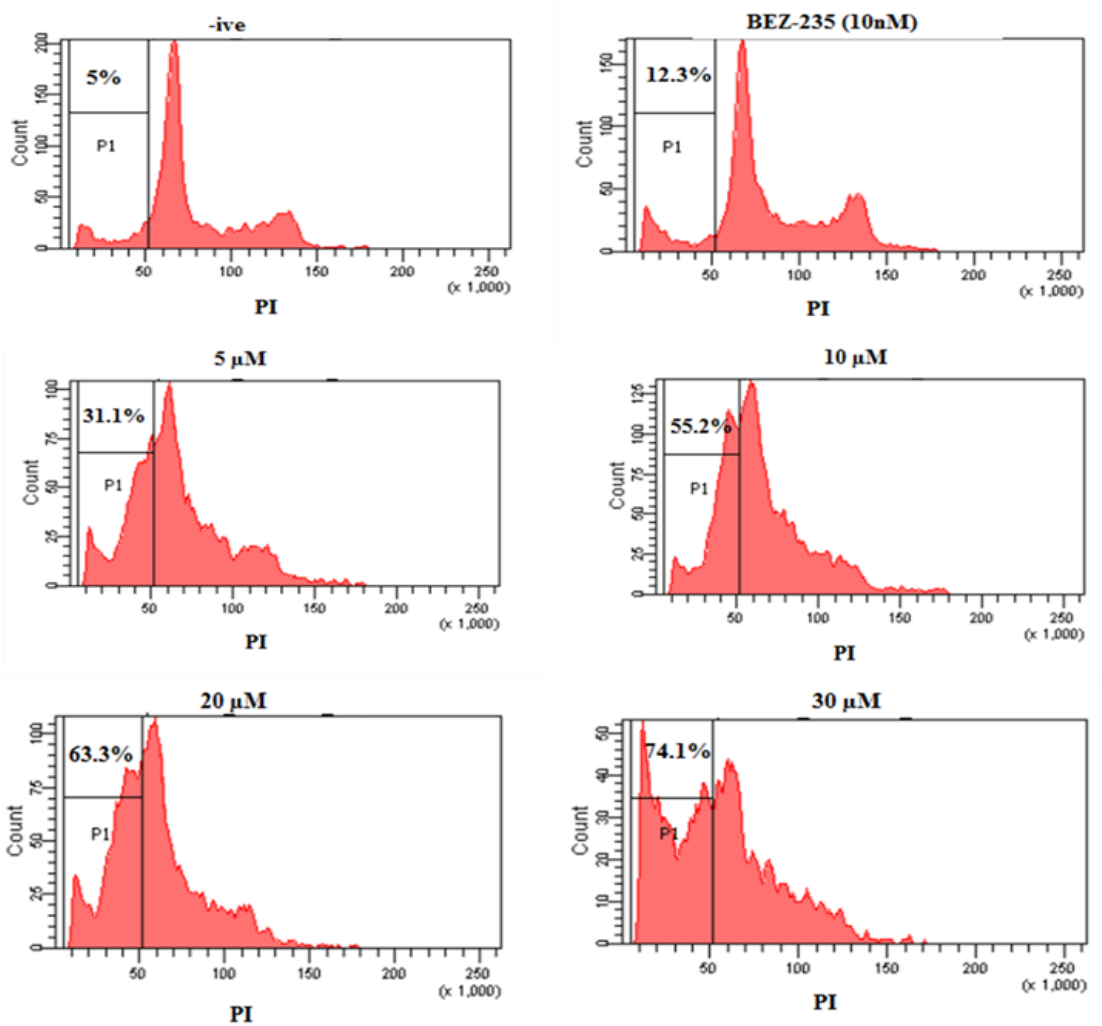

Figure 2. Cell cycle analysis of QCTN using NCI-H322 cancer cell line. The Cells exposed to different concentrations of QCTN and stained with PI to determine DNA fluorescence and cell cycle phase distribution.Fraction of cells for hypodiploid ( $\operatorname{sub~} \mathrm{G}_{0}-\mathrm{G}_{1}$ ) populations were analyzed from FL2A viz. cell counts is shown $(\%)$. Data are representative of the three independent experiments.

\subsection{Fluorescence microscopy for nuclear morphology.}

The NCI-H322 lung cancer cells showed significant changes in nuclear morphology, and apoptotic cell death increased after $48 \mathrm{~h}$ of quercetin treatment at 5, 10,20, and $30 \mu \mathrm{M}$ (Figure 3). The present study results showed that quercetin induced significant modifications in nuclear morphology, which resulted in cell death in lung cancer cells. Whereas in control cells, no changes were observed.

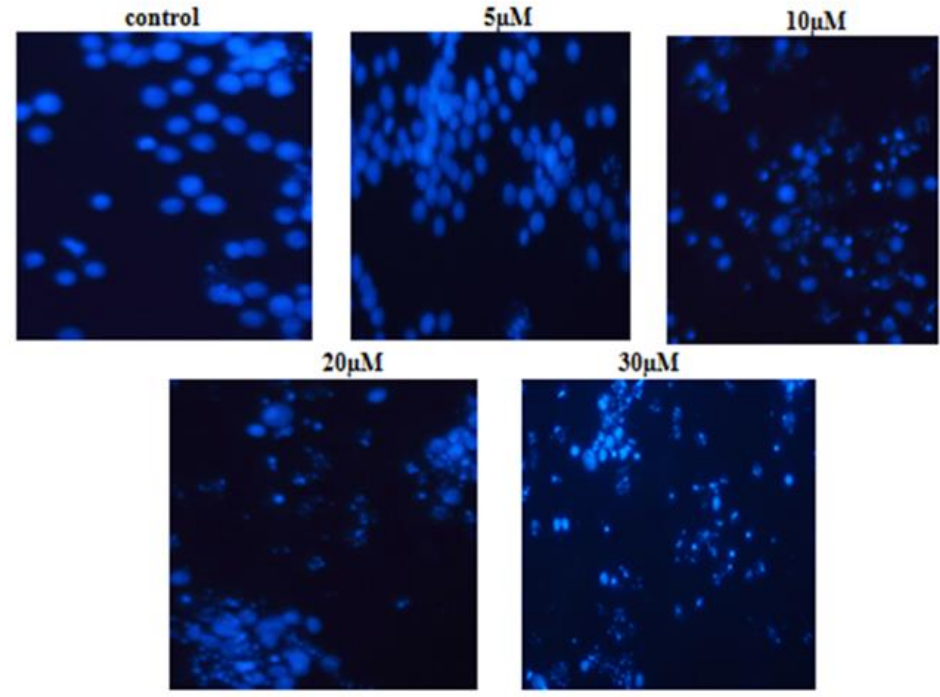

Figure 3. Gauging nuclear morphology in NCI-H322 cells after incubation with QCTN. The cells were exposed to specific doses of QCTN and stained with DAPI. The nuclear morphological alterations and apoptotic bodies were estimated and compared to the untreated control cells. 
3.4. Quercetin induces mitochondrial membrane potential $(\Delta \Psi m)$ loss.

The NCI-H322 cancer cells were observed for loss in mitochondrial transmembrane potential using rhodamine-123 by flow cytometry. In quercetin-treated cells, the MMP was found at 17.5, 22.7, 42.8, and 60.3\%, at 5, 10, 20, and $30 \mu \mathrm{M}$, respectively (Figure 4). In untreated control, cells have intact mitochondria and are metabolically active compared to damaged mitochondria in BEZ-235 (10 $\mathrm{nM})$ and quercetin-treated ones.
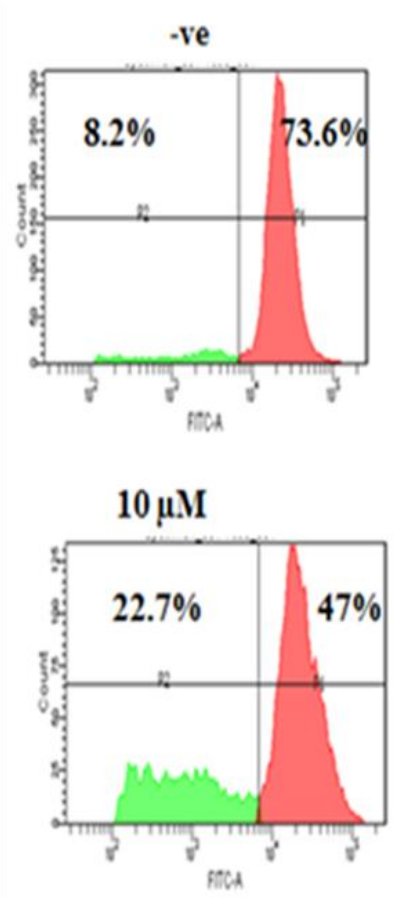
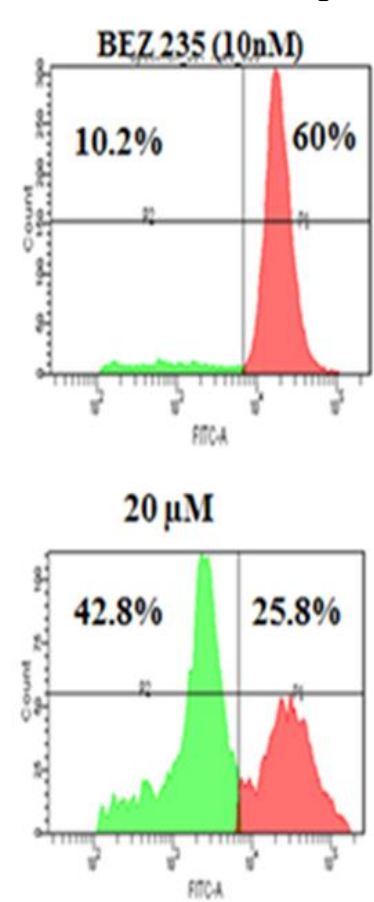

$5 \mu \mathrm{MI}$
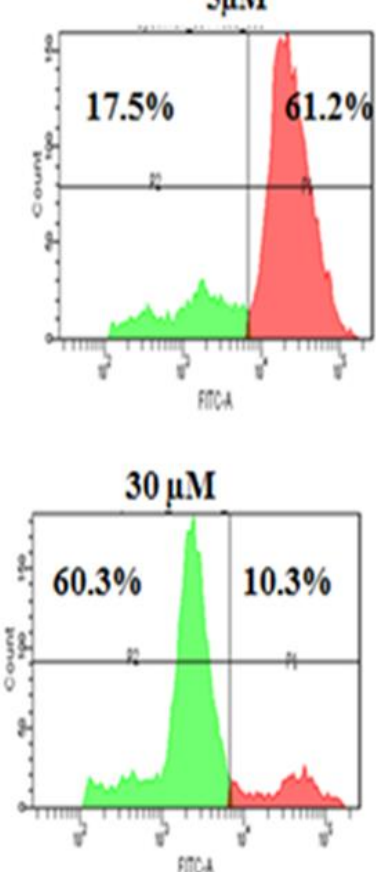

Figure 4. QCTN induced loss of mitochondrial membrane potential $(\Lambda \Psi \mathrm{m})$. NCIH-322 cells were incubated with QCTN, and thereafter, cells were stained with Rh-123 and analyzed in FL-1 versus FL-2 channels of flow cytometry. Data are representative of three experiments. A decrease in FL-2 fluorescence and a concurrent increase in FL-1 fluorescence were indicative of mitochondrial depolarization.

\subsection{Impairment of cell migration by quercetin.}

The quercetin-treated NCI-H322 cells were observed for cell migration by scratch mobility or wound healing assay. Quercetin-treated cells showed less wound closure as compared to untreated cells, which revealed a complete wound closure activity after $48 \mathrm{~h}$ (Figure 5). Quercetin in a dose-dependent pattern exhibited a decline in wound closure with a significant effect at $30 \mu \mathrm{M}$.

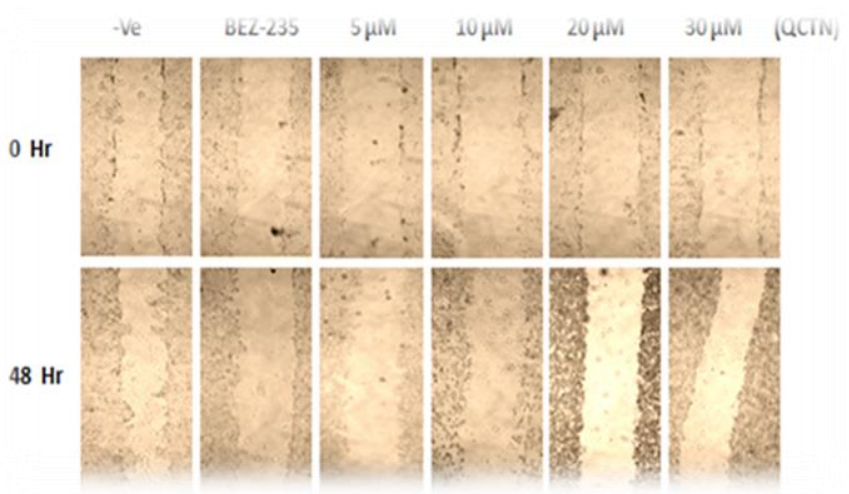

Figure 5. Inhibition of cell migration in case of lung cancer cells NCIH-322 after QCTN treatment. Cells were wounded by scratching with a pipette tip and treated with various concentrations of QCTN. The wounds were photographed (10X objective) at $0 \mathrm{~h}$ and $24 \mathrm{~h}$. Data are representative of the three independent experiments carried in triplicates. 
3.6. Administration of QCTN causes tumor inhibition in Ehrlich Ascites Carcinoma.

After quercetin has shown significantly in vitro anticancer activity, it was further studied for in vivo chemoprevention using Ehrlich Ascites Carcinoma mouse model. Importantly, quercetin does not show any toxicity to animals at the treatment dose of $50 \mathrm{mg} / \mathrm{kg}$ body weight as no mortality occurred during the experiment. In EAC-bearing mice, intraperitoneal administration of quercetin at 15,30 , and $50 \mathrm{mg} / \mathrm{kg}$ test doses caused tumor growth inhibition with $47.48,62.16$, and $89.02 \%$ impact, respectively as compared to the untreated control group (Table 2).

Table 2. Chemoprevention studies of bioflavonoid QCTN in the EAC experimental mouse model.

\begin{tabular}{c|c|c|c|c|c|c}
$\begin{array}{c}\text { Treatment Dose } \\
(\mathrm{mg} / \mathrm{kg}) \text { i.p. }\end{array}$ & Mortality & $\begin{array}{c}\text { Tumor vol. }(\mathrm{ml}) \\
\text { Mean } \pm \text { S.E }\end{array}$ & $\begin{array}{c}\text { Tumor wt. (gm.) } \\
\text { Mean } \pm \text { S.E }\end{array}$ & $\begin{array}{c}\text { Tumor cell count- } \\
\left(1 \times 10^{7}\right) \text { Mean } \pm \\
\text { S.E }\end{array}$ & $\begin{array}{c}(\%) \text { Tumor } \\
\text { cell growth }\end{array}$ & $\begin{array}{c}(\%) \text { Tumor } \\
\text { Growth } \\
\text { inhibition }\end{array}$ \\
\hline QCTN 15 & $0 / 7$ & $6.65 \pm 0.70$ & $6.52 \pm 0.69$ & $166.77 \pm 17.08$ & 52.52 & 47.48 \\
\hline QCTN 30 & $0 / 7$ & $4.14 \pm 0.43 * *$ & $3.72 \pm 0.43 * *$ & $120.14 \pm 9.14 * *$ & 37.84 & 62.16 \\
\hline QCTN 50 & $\mathbf{0} / 7$ & $\mathbf{1 . 0 7} \pm \mathbf{0 . 6 9} * *$ & $\mathbf{1 . 0 1} \pm \mathbf{0 . 6 5} * *$ & $\mathbf{3 4 . 8 5} \pm \mathbf{2 2 . 5 4} * *$ & $\mathbf{1 0 . 9 8}$ & $\mathbf{8 9 . 0 2}$ \\
\hline 5-FU 20 & $0 / 7$ & $0.71 \pm 0.22^{* *}$ & $0.52 \pm 0.22^{* *}$ & $6.14 \pm 2.28^{* *}$ & 1.9 & 98.1 \\
\hline $\begin{array}{c}\text { Control NS } \\
(0.2 \mathrm{ml})\end{array}$ & $0 / 10$ & $7.75 \pm 0.48$ & $7.65 \pm 0.61$ & $317.57 \pm 22.96$ & 100 & -
\end{tabular}

The extent of EAC-tumor growth inhibition was evaluated after administration of QCTN at test doses and compared with the untreated control group. Data are Mean \pm S.E. * represents significant $(\mathrm{p}=<0.05)$. ** represents highly significant $(\mathrm{p}=<0.01)$.

\section{Discussion}

Scientific reports have evidenced that Complementary and Alternative Medicines, including fruits, possess a significant amount of antioxidants with an anticancer activity that modulates various pathways [17-19]. The present study showed that quercetin bioflavonoid has cancer chemoprevention property against NCI-H322 lung cancer cells and revealed tumor growth inhibition in the EAC model. Among the four compounds tested against five different cancer cells, it was quercetin which produced significant anticancer activity against NCI-H322 lung cancer cells, whereas comparatively, the other three compounds (DAZ, CHI-A, and RUT) showed moderate cytotoxicity in a few cancer cell lines.

Previous reports have also shown that quercetin has anticancer activity against various cancer cells, including lung cancer cells [20-22]. However, no study stated that quercetin induced apoptosis in NCI-H322 cancer cells. In the present, quercetin showed remarkable anticancer activity with an $\mathrm{IC}_{50}$ of $24 \mu \mathrm{M}$ concentration.

The present study showed that quercetin induced apoptosis in NCI-H322 lung cancer cells in a concentration-dependent manner, as evidenced by the DAPI staining procedure and an increase in hypo-diploid DNA content. It was found that quercetin has a significant effect on the sub- $\mathrm{G}_{0}-\mathrm{G}_{1}$ phase of the cell cycle, which is essential for proliferation and apoptosis [23]. The NCI-H322 lung cancer cells treated with quercetin showed significant changes in nuclear morphology and cell death features, including cell shrinkage, chromatin condensation, and nuclear fragmentation. During apoptosis, mitochondrial membrane potential integrity is lost, which is observed by using rhodamine 123 dye [24]. The flow cytometric analysis of quercetintreated NCI-H322 cells showed a significant reduction in mitochondrial membrane potential compared to untreated cells. In cell migration assay, quercetin-treated NCI-H322 cells displayed that quercetin was very active in inhibiting lung cancer cell migration as monitored by measuring the gap size between treated and control cells. 
Further, quercetin was evaluated for in vivo antitumor activity employing the EAC mouse model, which is a reliable method and correlates with in vitro cytotoxicity. EAC results in edema formation, cellular migration, and formation and accumulation of ascitic fluid in the peritoneal cavity of the mouse [25]. The present study demonstrated that quercetin caused dominant tumor growth inhibition in EAC-bearing mice. The tumor growth inhibition includes body weight, tumor volume, tumor weight, and tumor cell count compared to untreated control groups.

\section{Conclusions}

The present study showed that quercetin exhibited significant anticancer activity against various cancer cells with high potency against NCI-H322 lung cancer cells by cell cycle arrest and MMP pathway. The quercetin also showed potent tumor growth inhibition in the EAC mouse model. The consequence of the current study has yielded encouraging results for safe and functional therapeutic applications of quercetin.

\section{Funding}

This research received no external funding.

\section{Acknowledgments}

The authors are thankful to Director CSIR-IIIM Jammu, India, for providing the necessary facilities and support.

\section{Conflicts of Interest}

The authors declare that there are no conflicts of interest.

\section{References}

1. Sung, H.; Ferlay, J.; Siegel, R.L.; Laversanne, M.; Soerjomataram, I.; Jemal, A.; Bray, F. Global Cancer Statistics 2020: GLOBOCAN Estimates of Incidence and Mortality Worldwide for 36 Cancers in 185 Countries. CA Cancer J Clin 2021, 71, 209-249, https://doi.org/10.3322/caac.21660.

2. Tan, Z.; Xue, H.; Sun, Y.; Zhang, C.; Song, Y.; Qi, Y. The Role of Tumor Inflammatory Microenvironment in Lung Cancer. Front Pharmacol 2021, 17, 1168, https://doi.org/10.3389/fphar.2021.688625.

3. Park, S.Y.; Boushey, C.J.; Shvetsov, Y.B.; Wirth, M.D.; Shivappa, N.; Hébert, J.R.; Haiman, C.A.; Wilkens, L.R.; Marchand, L.L. Diet Quality and Risk of Lung Cancer in the Multiethnic Cohort Study. Nutrients 2021, 13, 1614, https://doi.org/10.3390/nu13051614.

4. Carneiro, B.A.; El-Deiry, W.S. Targeting apoptosis in cancer therapy. Nat Rev Clin Oncol 2020, 17, 395-417, https://doi.org/10.1038/s41571-020-0341-y.

5. Zhang, Z.; Shi, J.; Nice, E.C.; Huang, C.; Shi, Z. The Multifaceted Role of Flavonoids in Cancer Therapy: Leveraging Autophagy with a Double-Edged Sword. Antioxidants 2021, 10, 1138, https://doi.org/10.3390/antiox10071138.

6. Choudhari, A.S.; Mandave, P.C.; Deshpande, M.; Ranjekar, P.; Prakash, O. Phytochemicals in Cancer Treatment: From Preclinical Studies to Clinical Practice. Front. Pharmacol 2020, 10, 1614, https://doi.org/10.3389/fphar.2019.01614.

7. Chen, B.H.; Hsieh, C.H.; Tsai, S.Y.; Wang, C.Y.; Wang, C.C. Anticancer effects of epigallocatechin-3gallate nanoemulsion on lung cancer cells through the activation of AMP-activated protein kinase signaling pathway. Sci Rep 2020, 10, 5163, https://doi.org/10.1038/s41598-020-62136-2.

8. Hsieh, K.Y.; Tsai, J.Y.; Lin, Y.H.; Chang, F.R.; Wang, H.C.; Wu, C.C. Golden berry 4ß-hydroxywithanolide E prevents tumor necrosis factor $\alpha$-induced procoagulant activity with enhanced cytotoxicity against human lung cancer cells. Sci Rep 2021, 11, 4610, https://doi.org/10.1038/s41598-021-84207-8.

9. Głowacka, A.; Rozpara, E.; Hallmann, E. The Dynamic of Polyphenols Concentrations in Organic and Conventional Sour Cherry Fruits: Results of a 4-Year Field Study. Molecules 2020, 25, 3729, https://doi.org/10.3390/molecules25163729. 
10. Yi, H.; Peng, H.; Wu, X.; Xu, X.; Kuang, T.; Zhang, J.; Du, L.; Fan, G. The Therapeutic Effects and Mechanisms of Quercetin on Metabolic Diseases: Pharmacological Data and Clinical Evidence. Oxid Med Cell Longev 2021, 2021, 6678662, https://doi.org/10.1155/2021/6678662.

11. Fonseca, L.R.S.; Silva, G.R.; Luís, A.; Cardoso, H.J.; Correia, S.; Vaz, C.V.; Duarte, A.P.; Socorro, S. Sweet Cherries as Anti-Cancer Agents: From Bioactive Compounds to Function. Molecules 2021, 26, 2941, https://doi.org/10.3390/molecules26102941.

12. Abid, S.; Khajuria, A.; Parvaiz, Q.; Sidiq, T.; Bhatia, A.; Ahmad, S. Immunomodulatory studies of a bioactive fraction from the fruit of Prunus cerasus in BALB/c mice. Intimmunopharm 2012, 12, 626-634, https://doi.org/10.1016/j.intimp.2012.02.001.

13. Qazi, A.K.; Hussain, A.; Aga, M.A.; Ali, S.; Taneja, S.C.; Sharma, P.R. Cell specific apoptosis by RLX is mediated by $\mathrm{NF \kappa B}$ in human colon carcinoma HC T-116 cells. BMC cell boil 2014, 15, 1471-2121, https://doi.org/10.1186/1471-2121-15-36.

14. Qazi, A.K.; Hussain, A.; Khan. S.; Aga, M.A.; Behl, A.; Ali, S.; Singh, S.K.; Taneja, S.C.; Shah, B.A.; Saxena, A.K. Quinazoline based small molecule exerts potent tumour suppressive properties by inhibiting $\mathrm{PI} 3 \mathrm{~K} / \mathrm{Akt} / \mathrm{FoxO} 3 \mathrm{a}$ signaling in experimental colon cancer. Cancer let 2015, 359, 47-56, https://doi.org/10.1016/j.canlet.2014.12.034.

15. Mesquita, D.P.; Amaral, A.L.; Ferreira, E.C. Activated sludge characterization through microscopy: a review on quantitative image analysis and chemometric techniques. Anal. Chim. Acta 2013, 802, 14-28, https://doi.org/10.1016/j.aca.2013.09.016.

16. Geran, R.I.; Greenberg, N.H.; Mac, M.M.; Schumacher, A.M.; Abbott, B.J. Protocols for screening chemical agents and natural products against animal tumors and other biological systems. Cancer Chemoth Rep 1972, $13,1-87$.

17. Huebner, J.; Prott, F.J.; Muecke, R.; Stoll, C.; Buentzel, J.; Muenstedt, K.; Micke, O. Economic Evaluation of Complementary and Alternative Medicine in Oncology: Is There a Difference Compared to Conventional Medicine. Med PrincPract 2017, 26, 41-49, https://doi.org/10.1159/000450645.

18. Costantini, S.; Colonna, G.; Castello, G. A holistic approach to study the effects of natural antioxidants on inflammation and liver cancer. Adv. in Nut and Cancer 2014, 159, 311-23, https://doi.org/10.1007/978-3642-38007-518.

19. Ferdous, U.T.; Yusof, Z.N.B. Medicinal Prospects of Antioxidants from Algal Sources in Cancer Therapy. Front Pharmacol 2021, 12, 593116, https://doi.org/10.3389/fphar.2021.593116.

20. Almatroodi, S.A.; Alsahli, M.A.; Almatroudi, A.; Verma, A.K.; Aloliqi, A.; Khan, A.A.; Rahmani, A.H. Potential Therapeutic Targets of Quercetin, a Plant Flavonol, and Its Role in the Therapy of Various Types of Cancer through the Modulation of Various Cell Signaling Pathways. Molecules 2021, 26, 1315, https://doi.org/10.3390/molecules26051315.

21. Vafadar, A.; Shabaninejad, Z.; Movahedpour, A.; Fallahi, F.; Taghavipour, M.; Ghasemi, Y.; Akbari, M.; Shafiee, A.; Hajighadimi, S.; Moradizarmehri, S.; Razi, E.; Savardashtaki, A.; Mirzaei, H. Quercetin and cancer: new insights into its therapeutic effects on ovarian cancer cells. Cell Biosci $\mathbf{2 0 2 0}, 10,32$, https://doi.org/10.1186/s13578-020-00397-0.

22. Tang, S.M.; Deng, X.T.; Zhou, J.; Li, Q.P.; Ge, X.X.; Miao, L. Pharmacological basis and new insights of quercetin action in respect to its anticancer effects. Biomed Pharmacother 2020, 121, 109604, https://doi.org/10.1016/j.biopha.2019.109604.

23. Basnakian, A.G.; James, S.J. A rapid and sensitive assay for the detection of DNA fragmentation during early phases of apoptosis. Nuc acids Res 1994, 22, 2714-5, https://doi.org/10.1093/nar/22.13.2714.

24. Qi, F.; Li, A.; Zhao, L. Cinobufacini, an aqueous extract from Bufobufogargarizans Cantor, induces apoptosis through a mitochondria mediated pathway in hepatocellular carcinoma cells. J Ethnopharm 2010, 128, 65461, https://doi.org/10.1016/j.jep.2010.02.022.

25. Hashem, M.A.; Shoeeb, S.B.A.; Abd-Elhakim, Y.M.; Mohamed, W.A.M.; The antitumor activity of Arthrospira platensis and/or cisplatin in a murine model of Ehrlich ascites carcinoma with hematinic and hepato-renal protective action. J. Funct. Foods 2020, 66103831, https://doi.org/10.1016/j.jff.2020.103831. 